\title{
Tytti Rantanen
}

\section{Toukokuusta kohti nollapistettä Kriisiytynyt kertomus poliittisena tilana: Marguerite Durasin Détruire, dit-elle ja Monique Wittigin Les guérillères}

Pariisin toukokuun 1968 mellakat esinäytöksineen olivat leimallisesti ja alun perin oppineiston ja kulttuuriväen liikehdintää. Protestit alkoivat Nanterren yliopistosta ja levisivät toukokuun alkupäivinä Latinalaiskorttelin ytimeen, Sorbonnen yliopiston ja École Normale Supérieure -eliittikorkeakoulun liepeille. Tehdastyöläiset yhtyivät taistelurintamaan vasta 14 . toukokuuta, joskin huomattavan voimakkaasti: viikon sisällä kaksi kolmasosaa Ranskan työväestöstä oli lakossa, ja useita kymmeniä tehtaita oli vallattu. Kuohunta jatkui kuun loppuun, jolloin presidentti de Gaulle piti radiopuheen ja hajotti kansalliskokouksen. Uudet vaalit 23. kesäkuuta olivat de Gaullen voitto, ja tilanne palautui päällisin puolin normaaliksi. Jälkipyykki sitä vastoin jatkui pitkään.

Käsittelen tässä artikkelissa eritoten Monique Wittigin teosta Les guérillères (1969, lainauksissa G) sekä Marguerite Durasin teosta Détruire, dit-elle (1969, lainauksissa DDE). ${ }^{5}$ Päädyin valitsemaan kronologiassa mellakkakevättä välittömästi seuraavat teokset juuri näiltä kirjailijoilta, koska molemmat ottivat osaa liikehdintään ja ulottavat politiikan teoksiinsa. Tämä poliittisuus näkyy nimenomaan niiden kerronnan radikalisoimisessa pelkän sisältötason aihevalinnan sijaan. Mellakoiden jälkeen omille siivilleen nousseessa feministisessä liikkeessä vaikuttanut Wittig tosin myöhemmin kieltäytyi niputtamasta teoksiaan sen paremmin naiskirjoituksen (écriture féminine) kuin muunkaan yksioikoisen poliittisen kirjallisuuden alle, sillä hän katsoi sen vain vahvistavan naismyyttiä kirjoittamisen luovan, materiaalisen prosessin tunnustamisen sijaan (Wittig 1992a, 59-60). Duras sitä vastoin avasi auliisti teostensa politiikkaa erinäisissä kirjoituksissa ja haastatteluissa. Analyysin kautta tarkastelen, miten Wittig, Duras tai toisaalta Maurice Blanchot osallistuivat omilla kirjoituksillaan kertomuksen kriisiyttämiseen. Tarkastelen tämän kriisiyttämisen ja suoranaisen sabotaasin poliittisia ulottuvuuksia sekä sitä, mitä näillä kirjoittajilla oli tarjota rampautetun kertomuksen tilalle - vaiko mitään.

Ranskan älymystön suhdetta maolaisuuteen tutkinut Richard Wolin $(2010,20)$ huomauttaa terävästi, että varsinainen Kiina lakkasi jo varhain olemasta empiirinen viittauskohde - ranskalaiselle äärivasemmistolle siitä tuli pikemminkin trooppi, poliittisen mielikuvituksen heijaste. Tutkimuksensa alkusivuilla Wolin maalaa ilkeähkön, mutta herkullisen kuvan maolaisuuden fiktiivisestä pohjasta: mitä vähemmän 
eliittiopiskelijat tiesivät nyky-Kiinan oloista, sen parempi, sillä Suuren Puheenjohtajan käynnistämä kulttuurivallankumous oli heille Rorschachin musteläiskätesti, johon heijastaa radikaaleja poliittisia toiveita ja fantasioita (sama, 3). Wolinin kuvaus käy tämän artikkelin embleemistä. Tapahtumiin osallistuneet ajattelijat ja kirjoittajat väistämättä toteuttivat poliittisessa toiminnassaan kirjallisia näkemyksiään ja pyrkivät vaikuttamaan laajemmin toukokuun luovan luokan tekstuaalisiin malleihin. Niinpä mellakat eivät vaikuttaneet vain yksisuuntaisesti kirjailijoiden tyyliin ja ajatteluun, vaan niistä tuli fantasmaattinen koekenttä, jonka myötä kirjoituksen avantgardea saattoi lyhyen aikaa elää todeksi.

Aktivistikirjailija Dionys Mascolon $(1993,317)$ mukaan viimeistään toukokuun liikehdintä todisti, että "teoria oli läpäissyt kansanjoukot", opiskelijoista ja älymystöstä oli tullut oma sosiaaliluokkansa. Bernard Brillant kuvaa, kuinka taideinstituutioiden, tärkeimpänä Odéonin teatterin, valtaus oli ennen kaikkea symbolinen ele, jolla kirjailijat ja muut taiteilijat tehdastyöläisten innoittamina sovelsivat taistelun malleja oman tuotantojärjestelmänsä rakenteisiin. Kulttuuriväen panos kumousliikehdintään oli yritys panna iskulause "Valta mielikuvitukselle!" ("L’imagination au pouvoir!") täytäntöön. (Brillant 2003, 157.) Teorian ja mielikuvituksen läheisyys näkyy myös siinä, että tapahtumat on mahdollista nähdä yhtenä väylänä, jonka kautta kirjoittajat (siinä missä elokuvan- ja teatterintekijätkin) työstivät eteenpäin jälkimodernille kulttuurille keskeistä kertomusmuodon ja merkityksenmuodostamisen kriisiä.

Kokeellisen kirjallisuuden juuret juontavat kauas 1960-lukua varhemmas, ja avantgarde on usein lähtökohdiltaan nivoutunut politiikkaan - joskin harvemmin mihinkään sementoituneeseen puoluepolitiikkaan. Myöskään ranskalaisen 1960-luvun kirjallisuuden kertomusmuodon radikalisoituminen ei kehkeytynyt ja vaikuttanut vain jonkin umpikirjallisen tyhjiön sisällä, vaan sitä on syytä tarkastella yhteydessä poliittiseen aktivismiin. Toukokuun tapahtumat vaikuttivat syvästi myös kirjalliseen keskusteluun eräänlaisena kulminaationa aikakauden avantgardistisille tendensseille. Ranskan 1960- ja 1970-luvun taitteen vasemmistoaktivismin kenttä on toraisa, ristiriitainen ja kirjava, mutta toukokuun 1968 liikehdinnällä on kirjalliset ulottuvuutensa jo sitä kautta, että useampikin kirjailija (nimekkäimpinä Jean-Paul Sartre, Marguerite Duras, Maurice Blanchot, Monique Wittig) osallistui mielenosoituksiin, toimintakomiteoihin ja muuhun enemmän tai vähemmän järjestäytyneeseen protestointiin. ${ }^{1}$ Osa taas, kuten Tel Quel -ryhmä, myöhästyi varsinaisesta mellakasta (Wolin 2010, 132-134; Bolgár 1969, 197-198), mutta ehätti vielä seuraavan vuosikymmenen alkupuolella maolaisuuden aaltoon.

Kaikkea kokeellisuutta ei tokikaan voi palauttaa aktivismiin. Esimerkiksi Alain Robbe-Grillet pysytteli kriittisen etäisyyden päässä toukokuun mellakoista, mutta venytti yhtä kaikki omissa teoksissaan sekä elokuvallisen että kirjallisen kerronnan 
rajoja äärimmilleen. Liikehdinnän sympatiseeraajienkin kohdalla vaikutussuhde poliittisen aktivismin ja kirjallisen keskustelun välillä on monisäikeinen ja ristiriitainen. Tapahtumien jäljittäminen varsinaisista kaunokirjallisista teoksista on vielä monimutkaisempaa, sillä kuten Maurice Blanchot $(2008,157)$ tuoreeltaan julisti lentolehtistekstissä, "Toukokuussa ei ole kirjaa Toukokuusta". ${ }^{2}$ Sittemmin yritystä on ollut, mutta Patrick Combes (2008, 202-210) pitää aihetta eksplisiittisesti käsitteleviä romaaneja pääsääntöisesti esteettisinä epäonnistumisina: ne ovat kaukana siitä kirjoituksen vallankumouksellisuudesta, jota "toimintakomiteoissa" (varsinkin opiskelijoiden ja kirjailijoiden toimintakomiteassa, Comité d'Action Étudiants-Écrivains) hahmoteltiin. ${ }^{3}$ Tässä mielessä toukokuiset jäljet eivät johdakaan teosten aihevalintoihin ja sisältöön, vaan kieleen ja rakenteisiin.

Dominique Viart $(2008,11)$ muistelee, että toukokuusta oli hankala kertoa, sillä kerronta olisi vaatinut eeppistä rekisteriä - ja epiikka oli paitsi pois muodista myös mallina täysin tuhottu sotienjälkeisessä kulttuurimaisemassa. Juuri kerronnan hankaluus onkin oireellista: radikalisoituneessa ilmapiirissä kertomusmuoto perinteellisimmässä mielessä selvärajaisine, psykologisesti läpinäkyvine henkilöhahmoineen ja sulkeumaan pyrkivine kompositioineen koettiin kestämättömäksi yhteiskunnan ja taidemuodon kehityksen kannalta (ks. esim. Just 2010, 360). Kertomukseen kohdistuvasta nihkeydestä kielii konkreettisesti sekin, että siinä missä Monique Wittigin esikoisteos Opoponaks (L'opoponax, 1964) tai suurin osa Marguerite Durasin kirjallisesta tuotannosta L'amante anglaise -teokseen (1967) asti kantaa nimensä perässä attribuuttia 'roman', kumpikin kirjailija hylkäsi koko määreen vuoden 1968 jälkeen ilmestyneissä teoksissaan. "Romaanit" palaavat teosluetteloon vasta 1980-luvun puolivälissä - Wittigillä Virgile, non -teoksen (1985) ja Durasilla autofiktiivisen jättimenestyksen, Rakastajan (L'amant, 1984) myötä. ${ }^{4}$

Sen sijaan Wittigin teoksia Les guérillères ja Le corps Lesbien (1973) tai Durasin apokalyptissävyistä kolmikkoa Détruire, dit-elle, Abahn, Sabana, David (1970) ja L’amour (1971) ei ole määritelty nimilehdellä tai teosluetteloissa millään lailla. $\mathrm{Ne}$ sisältävät proosan lisäksi myös piirteitä runoudesta ja draamasta. Cahiers du cinéma -lehteen Jean Narbonin kanssa Durasia haastatellut Jacques Rivette mainitsee Détruire, dit-elle -kirjan lukemisen muistuttaneen käsikirjoituksen lukemista kerronnan niukkuuden vuoksi (Duras 1969, 45). Tämä ei ole ihme, sillä teos on tapahtumiltaan (kaksi miestä ja kaksi naista etsivät rajojaan ja sulautuvat yhdeksi) ja miljööltään (kummallisen autiolta vaikuttava hotelli uhkaavan metsän reunassa) äärimmäisen rajattu ja viitteellinen. Wittig puolestaan kuvailee naisten valtaannousua esittävää teostaan Les guérillères eeppiseksi runoksi tai kollaasiksi. Toisaalta hän hakee vertailukohtaa Bertolt Brechtin antiaristoteelisesta, dialektisesta dramaturgiasta tai elokuvaohjaaja Jean-Marie Straubin "aukkoisesta taiteesta" (lacunary art), joka kirjoitukseen sovellettuna merkitsee 
keskeytysten luomista, lauseiden kieliopin puhkomista ja kerronnan konventionaalisen järjestyksen horjuttamista (Wittig 2005, 37-38).

Keskeytykset, puhkominen ja horjuttaminen ovat aktiivista sabotaasia, siinä missä Durasin kertomus kriisiytyy ensisijaisesti vähäeleisyytensä ja fragmentaarisuutensa kautta. Daniel Just summaa Durasin lietsovan kirjallisuutta vastustamaan sille osoitettua funktiota merkityksen kommunikoijana. Kerronta ei ole vain viestintää, sillä siihen liittyy aina poliittisia juonteita. (Just 2010, 359.) Kun kieli riisutaan liiallisista määreistä, jäävät havaitsemisen, ymmärtämisen ja tulkitsemisen rakenteet hankaluuksineen ja estoineen paljaammin esille.

Miten kulttuurihistoriallinen konteksti taipuu elimelliseksi osaksi kertomuksentutkimusta? Jacques Derrida ilkeilee jo vuodelta 1963 peräisin olevassa tekstissään "Force et signification" ("Voima ja merkitys") strukturalisteille: "Muoto kiehtoo, kun ei ole enää voimia ymmärtää sen sisältämää voimaa. Toisin sanoen luomista. Siksi kirjallisuudentutkimus on kaikkina aikoina olemukseltaan ja kohtaloltaan strukturalistista.” (Derrida 2010, 11.) Klassinen narratologia on usein jättänyt formaalin tarkastelunsa ulkopuolelle kirjallisten muotojen takana vaikuttavat voimat ennen 1980- ja 1990lukujen feminististä ja ideologiakriittistä trendiä (Fludernik 2005, 45; Shen 2005, 141). Kahden viime vuosikymmenen aikana narratologisen tutkimuksen keskeisin konteksti on ollut kognitiivisten lukemisen ja tulkinnan prosessien huomioonottaminen (Fludernik 2005, 49; Shen 2005, 155), mutta näissä tutkimuksissa oletettu 'lukija' on usein pikemmin abstrakti konstruktio kuin mikään tosi olento.

Kertomusten puntarointi suhteessa kulttuurihistorialliseen synnyinmaisemaansa jää edelleen helposti vain nopeasti ohitettavaksi taustoitukseksi. Kuten Brian McHale $(2005,67)$ toteaa, strukturalistisen ja historisoivan suuntauksen välillä on usein jännitteinen suhde, jota on hankala saada tasapainoon. Silti jotkin teokset ja tekijä(ryhmät) tuntuvat houkuttelevan muita enemmän aikansa kulttuuripoliittisen keskustelun huomioimiseen. Se ei välttämättä johdu siitä, että teokset itsessään olisivat suoria kommentaareja, vaan joskus myös siitä, että tekijän puheenvuorot ja muut ulostulot tai koko aikalaiskeskustelu lähenevät kirjallista performanssia. ${ }^{6}$

David Darby $(2001,839)$ ehdottaa, että klassisen narratologian laiminlyömää rajankäyntiä intra- ja ekstratekstuaalisen aineksen välillä voidaan tarkastella eritoten piilevän ${ }^{7}$ tekijän (implied author) kaltaisen konstruktion kautta. Omissa tutkimuskohteissani aikalaisteoria ja -politiikka eivät jää piilevän tekijän vihjeiden varaan, vaan nivoutuvat niin tiiviisti osaksi tekstiä ja sen syntyä, että ne lakkaavat olemasta ekstratekstuaalisia lisukkeita. Jo Gérard Genette, klassisen narratologian peruspilari, ymmärsi huomioida tämän vuonna 1966 pitämässään puheenvuorossa "Raisons de la critique pure" (julkaistu kokoelmassa Figures II vuonna 1969). Genette kuvaa, miten kirjoittajat kuten Jorge Luis Borges tai Maurice Blanchot ovat kirjoituksissaan vakiinnuttaneet 
modernin kritiikkimuodon, "luomattomien luojien kritiikin" (critique de créateurs sans création), joka keskittyy kuvaamaan ennen muuta "tyhjyyttä" ja "syvää toimettomuutta" (désœuvrement profond). Samalla hän kuitenkin huomauttaa, että tämänkaltainen moderni kritiikki on itsessään olennainen osa aikakautensa kirjallista luomista: kirjoitus ei ole enää pelkkä ilmaisuväline, vaan siitä muotoutuu itsenäinen ajattelun tila (lieu même de sa pensée). (Genette 1969, 21-22.) Jos kirjoitus ymmärretään tilaksi, se tila voi yhtä hyvin muuntua koelaboratorioksi tai taistelukentäksi.

\section{Älyllistä harvaintaidetta vai taistelu määritysvallasta?}

Mirja Bolgár taltioi kapinakevään kirjallisia tuntoja tuoreeltaan esseekokoelmaansa Pariisin päiviä (1969). Kesän 1968 jo viiletessä alkusyksyyn hän jaksaa vielä toivoa, että muun muassa seinäkirjoituksina ja julisteina levinneiden iskulauseiden spontaanius, kollektiivisuus ja surrealismi voisivat raikastaa Ranskan kirjallisuutta, "jonka monet ahkerat sanan insinöörit ovat viime vuosina tahtoneet kesyttää älylliseksi harvaintaiteeksi” (Bolgár 1969, 11-13). ”Ahkerilla sanan insinööreillä” Bolgár viitannee kulttuuri- ja yliopistopiirit läpäisseeseen strukturalismin nousuun sekä samanaikaiseen merkittävään kirjallisuussuuntaukseen, joka ulkoapäin on nimetty "uudeksi romaaniksi" (nouveau roman) ${ }^{8}$ Politisoituneessa keskustelussa kumpaakin pidettiin liian teoreettisena ja jähmeänä keskustelukenttänä kouriintuntuvaan todellisuuteen nähden (ks. esim. Dosse 1997, 125). Lähestyvä 1970-luku toi tullessaan uudenlaisen kertomuksen painotuksen, joka tunnusti kertomusmuodon mahdollisuuden inhimillisen kokemuksen jäsentämisen ja maailman hahmottamisen välineenä (Meretoja 2010). Vaikka kokeellisuus jäikin vaikuttamaan marginaaliin niin kirjallisuuden kuin elokuvankin puolella, toukokuun vallankumouksellinen hetki ja sen hiipuminen olivat taitekohta matkalla avantgardea yleishumanistisempaan suuntaan.

Hanna Meretoja $(2007,185)$ luonnehtii uutta romaania hyötyajattelusta irtoavaksi, uusia muotoja etsiväksi tutkimustoiminnaksi. François Dosse $(1997,221)$ näkee suuntauksen strukturalismin koekeittiönä: kirjailijat hylkäsivät kerronnan sosiologisen todenkaltaisuuden keskittyäkseen kehittelemään mahdollisia, modaalisia tarinoita kaikkine variaatioineen. Meretojan (2010, 23, 160-180) mukaan sodanjälkeisinä vuosina kertomusmuoto ylimalkaan näyttäytyi ongelmallisena, sillä sen koettiin edustavan eettisesti ongelmallista järjestykseen asettamista, jossa todellisuus pakotettiin luonnollisilta vaikuttaviin kategorioihin. Uuden romaanin poliittisuus kytkeytyi taisteluun juuri tätä "luonnollisuuden myyttiä" vastaan; lukijan huomio vangittiin jatkuvaan liikkeeseen ja merkitysten epävakauteen (Meretoja 2007, 193, 196; 2010, 170-178). Kertomushistoriallisesti onkin luontevaa, että 2000-luvun "luonnottoman [tai epäluonnollisen] narratologian" (unnatural narratology) keskeinen mutta kiistelty pää-äänitorvi Brian Richardson ammentaa useat esimerkkinsä uuden romaanin ylipapilta, Alain Robbe- 
Grillet'ltä (ks. esim. Richardson 2006, 7-9). Richardson tosin ei pysähdy pohtimaan Robbe-Grillet'n mutkikkaiden kerrontaratkaisujen eetosta; niinpä ne jäävät ajelehtimaan irrallisena osana oudon ja "äärimmäisen" fiktion vuota.

Merkityksenmuodostuksen valtasuhteiden jännitteisyys on olennainen osa sekä Wittigin että Durasin jo vuotta 1968 edeltävää tuotantoa. Kirjallisessa debyytissään Opoponaks Wittig kuvaa koulutyttökollektiivin dynamiikkaa, jonka askelmerkkejä ja subjektiviteetin rajoja tapaillaan keskinäisessä puhetulvassa. Durasin romaanissa Lol V. Steinin elämä (Le ravissement de Lol V. Stein, 1964) eripersoonaisten kertojaäänien välillä häilyvä Jacques Hold yrittää sulautua nimihenkilön mieleen. Seuraavassa romaanissa Varakonsuli (Le vice-consul, 1965) taas valkoinen siirtomaavirkailija Peter Morgan yrittää ottaa kirjoittamalla kantaakseen hullun kerjäläisnaisen tuskan. Kumpikaan ei pääse juuri omia fantasioitaan pidemmälle.

Marguerite Duras liitetään usein osaksi uutta romaania, vaikka hän itse luokittelun torjuikin. Diane Griffin Crowder $(2005,79)$ puolestaan muistuttaa, että myös Monique Wittig oli uransa alkuvaiheessa hedelmällisessä yhteydessä löyhän ryhmittymän kirjailijoihin, Robbe-Grillet'n lisäksi Nathalie Sarrauteen ja Claude Simoniin. Vähintään assosiaatiotasolla Wittig liittyy "sanan insinööreihin" jo esikoisromaaninsa erikoisen passiivimuotoisen 'on'-kerronnan vuoksi. Griffin Crowder (sama) summaa uuden romaanin kirjailijoiden vastustaneen paitsi realistista, "balzacilaista" perinnettä, myös Sartren "sitoutuneen kirjallisuuden" (littérature engagée) konseptia. Vaikkei seurailisikaan mitään koherenttia ideologiaa tai puoluelinjausta, sanataiteilijalla on silti rajattomat mahdollisuudet toteuttaa tekstuaalista politiikkaansa uudelleenmuovaamalla kieltä ja kirjoitusta.

Usein tämä toiminta pyrkii tempomaan sijoiltaan myös edeltävän kirjallisen tradition, joka käännetään nurin niskoin. Kuten Hélène Cixous naiskirjoituksen merkkiteoksessa, esseessään "Medusan nauru", julistaa, "sanan valtaamisen"9 aktissa nainen "tulee rytinällä historiaan". Nainen kirjoittaa "takoakseen itselleen logoksen vastaisen aseen”, jolla jättää jälkensä niin kirjoitettuun kuin puhuttuun kieleen. (Cixous 2013, 44, kursivointi alkuperäinen.) Wittigin kohdalla tämä näkyy ilmiselvimmin patriarkaalisen kaanonin kielen ja konventioiden feminisoimisessa, teoksessa Le corps lesbien jopa kirjoituksen "lesbosaationa".

Roland Barthes tekee klassikkonsa $S / Z$ alussa jaon "luettavan" (lisible) ja "kirjoitettavan" (scriptible) tekstin välillä. Ensin mainitun tarjoama lukijasuhde on asiakassuhde, passiivinen kuluttamistapahtuma, jossa ei ole tilaa omalle merkityksiä muuntavalle leikkisälle luomistyölle, päinvastoin kuin viimeksi mainitussa. (Barthes 2000, 10-11.) Militantti mutta eloisa Les guérillères kutsuu lukijan nauramaan kanssaan patriarkaalisen kulttuurin valmiiksipureskelluille, vuoroin demonisoiville, vuoroin alentuvasti romantisoiville käsityksille naisten anatomiasta ja luonteenlaadusta. Teos kuvaa miesten ja 
naisten välistä sotaa, jossa naiset juuri Cixous'n esittämällä tavalla valtaavat "rytinällä" sanan ja ottavat puhumalla haltuun tilan, jonka patriarkaalinen essentialismi on heiltä anastanut. Taistelu käydään kielessä ja kielellä:

He sanovat löytäneensä kipsiseinästä kaiverruksia, joissa vulvat on kuvattu niin kuin lapset piirtävät aurinkoja monin eri suuntiin osoittavin sätein. $\mathrm{He}$ sanovat, että on kirjoitettu, että vulvat ovat ansoja ruuvipenkkejä puristimia [--]. He sanovat että vulvia on verrattu aprikooseihin granaattiomenoihin viikunoihin ruusuihin neilikoihin pioneihin päivänkakkaroihin. He sanovat, että vertauksia voidaan luetella kuin litanioita. $(\mathrm{G}, 43 .)^{10}$

Suomen kielen 'he' ei välitä radikaalia tehoa, joka sisältyy alkukieliseen pronominiin 'elles'. Teos on kerrottu lähes kauttaaltaan feminiinin monikon kolmannessa persoonassa, joka on ranskassa harvinaisempi kuin maskuliini 'ils'. Monikon maskuliiniin siirrytään välittömästi, jos ryhmään kuuluu yksikin mies. Wittig tosin olisi suomen sukupuolineutraaliuteen tyytyväinen: hän on täsmentänyt, ettei tähtää pronominivalinnallaan niinkään maailman feminisoimiseen, vaan osoittamaan kielen sukupuolierottelun vanhanaikaisuuden, nostamaan poikkeuksen kerrankin normiksi (Wittig 1992c, 84-87). Näin hän itse asiassa asettuu vastahankaan muun muassa Cixous'n ja Luce Irigarayn edustamaan, sukupuolieroa korostavaan feminismiin nähden (ks. Grosz 2013, 67-71). Wittig ei halua pitäytyä vain "naiskirjoituksen" omaleimaisuuden varmistelussa, vaan pyrkii ulottamaan vallan uusjaon kaikkeen kieleen ja kirjoitukseen.

Toinen Wittigin teosta leimaava piirre on suullisen kerronnan nostaminen kirjoitusten pysähtyneisyyttä dynaamisemmaksi voimaksi. Kertoessaan toisilleen tarinoita (sekä osana kertomusta läpi teoksen katkovaa pitkää, lähinnä etunimistä koostuvaa runoa) naiset nousevat nimettömästä kollektiivista nimetyiksi yksilöiksi, kuten Fabienne Jouy, Anénome Flavien tai Danièle Nervi. Myös Durasin Détruire, dit-elle luottaa enemmän dialogiin kuin eläytyvään kuvailuun tunnekuohujen välittäjänä. Hotellissa metsän laidalla aviopari Alissa ja Max Thor sekä mies nimeltä Stein obsessoituvat sekä toisistaan että salaperäisestä, masentuneesta rouva Élisabeth Alionesta. Lakonisten keskustelujen myötä mutta kuin jonkin maagisen väistämättömän voiman ajamina kaikki kolme, lopulta neljä sulautuvat rajoiltaan häilyväksi joukkioksi (ks. Duras 1969, 48), jonka tajunnanvirtaan lukijalla ei juuri ole pääsyä dialogin ohitse:

He ovat puun varjossa. Élisabeth palaa hitaasti. Alissa sulkee silmät. Élisabeth asettuu lepotuoliin. Hän sulkee vuorostaan silmänsä. Hänen kasvoillaan lähtöhymy katoaa vähitellen ja antaa tilaa kaikenlaisen ilmeen poissaololle. (DDE, 37. $)^{11}$

Daniel Just kiteyttää oivallisesti Durasin henkilöhahmojen minimalismin etiikan. Avoimuus saavutetaan vain säilyttämällä kohtaajien toiseus vaikka ymmärryksen kustannuksella. Ymmärtämisessä on vaarana henkilön toiseuden laimentaminen, niinpä 
Durasin kirjoituksessa vain voipunut ja ymmärryksestä pidättäytyvä hahmo tekee oikeutta uudenlaisen minuuden eettisille ja poliittisille reunaehdoille (Just 2010, 372). Tämä Emmanuel Levinasin filosofiasta kumpuava epäluulo ymmärtämistä ja kertomusmuotoa kohtaan on toki olennainen Durasin lisäksi muillekin sodanjälkeisille ranskalaiskirjailijoille (Meretoja 2010, 160-166). Periaate muistuttaa myös Jean-Luc Nancyn "Tunkeilija”-esseessään hahmottelemaa vieraan kohtaamisen etiikkaa: vieraaseen ei koskaan voi uppoutua täydellisesti, sillä sen olemus on aina tunkeileva ja luvaton, hämmentävä ja jopa häiritsevä: "Muutoin vieraan vieraus sulautetaan itseen, ennen kuin hän on ylittänyt kynnyksen, eikä kyse ole enää vieraudesta." (Nancy 2010, 127-128.) Mirja Bolgárin haastattelussa Duras arvuuttelee ihmiskuvaansa:

Voitteko te sanoa, mitä nämä romaaneissani liikkuvat ihmiset ovat? Minä en tiedä. Jotkut kutsuvat niitä siirtymäkauden ihmisiksi, mutanteiksi. Ehkä joskus vuonna 2000 päs̈stään siihen, että ei ole enää egoismia, mustasukkaisuutta, omistushalua, häveliäisyyttä? Joka tapauksessa he ovat todistajia hajalle räjähtäneestä maailmasta. [--] Miten tuo tuhoutuminen tapahtuu, en tiedä. Ehkä tietoisuuden on hajottava, sielun, individualismin? Tiedän vain, että tuho on edessä. (Bolgár 1969, 121.)

Jako siirtymäkauden ihmisen ja ymmärtämisessä pyristelevän konservatiivin välillä käy selväksi, kun syntymättömän lapsensa menettäneen Élisabeth Alionen mies, säilyketehtailija Bernard Alione tulee noutamaan vaimoaan hotellista ja lounastaa yhteenhitsautuneen erikoisen seurueen kanssa:

- Te olette selvästi hyvin kiinnostunut hänestä, sanoo Bernard Alione.

- Kyllä.

- Saisiko tietää miksi? ääni on jälleen voimistunut.

- Kirjallisista syistä, sanoo Stein. Hän nauraa.

Stein nauraa. Alissa katsoo hänen nauruaan häikäistyneenä.

- Onko vaimoni romaanihenkilö? sanoo Bernard Alione.

Hän naurahtaa. Hänen äänensä on yrityksestä huolimatta yhä soinniton.

[--

- En näe, mitä voisitte kertoa hänestä... On totta, että nykyään romaaneissa

ei enää kerrota yhtään mitään... Siksi minä luen niitä niin vähän... että...

Hän katsoo heitä. He ovat vakavoituneet. He eivät kuuntele häntä. Élisabeth

kulkee läpi ruokasalin.

Hän istuutuu. Hänen silmänsä ovat jääneet unessa aivan auki.

Hiljaisuus.

- Oksensitteko? kysyy Alissa.

Élisabethin on hyvin vaikea muodostaa sanojaan.

- Kyllä.

- Millaista se oli?

Élisabeth miettii. Hän hymyilee.

- Miellyttävää, hän sanoo.

-Hyvä, sanoo Stein. Hyvä. (DDE, 118-119.) ${ }^{12}$

Bernard Alione ei laiskana lukijana osaa nähdä mielenkiintoa kirjallisen olemisen näennäisessä mielettömyydessä ja ravistelevassa tyhjyydessä. Niinpä hän ei näe haurasta 
vaimoaankaan kerronnan arvoisena, kun taas muulle seurueelle hellyys ja kiintymys voivat saada myös kirjallisia muotoja ja syitä.

\section{Kirjoituksen kommunismi}

Toukokuun 1968 mullistaman kirjoituksen uusia reunaehtoja hahmotellaan opiskelijoiden ja kirjailijoiden toimintakomitean ensimmäisessä julkilausumassa, joka on anonyymi ja kollektiivinen tuotos mutta josta on tunnistettavissa komiteassa toimineen Maurice Blanchot'n kirjallisuuskäsitys. Kirjallisuuden tulee katkoa välinsä perinteisiin käytänteisiin ja etuoikeuksiin; anonyymit tekstit tähtäävät kirjoituksen kommunismiin. Katkelmallisuus mahdollistaa monimuotoisuuden. Epäjatkuvuus ja sulkeutumattomuus ovat osa radikaalimman kielen etsintää. Tämän kulttuurin ja puhuntojen ulkopuolella väijyvän kielen tulee jatkaa loputonta kyseenalaistamista. (Blanchot 2008, 149-151.) Katkosten liike kirjoituksen syvimpänä olemuksena resonoi Blanchot'n esimerkiksi teoksessa L'entretien infini $(2006,9)$ hahmotteleman moniaalle hajautuvan kielen kanssa.

Wittigin teoksessa kerronnan konventionaalisen järjestyksen horjuttaminen merkitsee kerronnan kronologian hylkäämistä. Teos koostuu kolmesta osasta, joiden kaikkien välissä on suuri ympyrä - tai nolla. Kertomus ei jäsenny lineaarisesti, vaan se voidaan lukea lopusta alkuun, jolloin se muodostaa erän̈laisen vastakronologian. Kertomuksen lähtöpiste on naisten (elles) ja miesten (ils) välinen sota, mutta tämä sota ja naisten voitto sijoittuu painetussa teoksessa vasta sen kolmanteen ja viimeiseen osioon. Ensimmäinen osio näyttää lukijalle nurinniskoin käännetyn maailman, jossa he, "sissittäret" (guérillères) etsivät omaa kieltään ja omia määritelmiään. Mutta ensin heidän täytyy löytää tiensä "muinaisten merkkien ja representaatioiden kuolleen kulttuurin labyrintin lävitse - tarinoiden, faktojen, historian, muinaisten symbolien lävitse", kuten Wittig (2005, 41-42) heidän odysseiaansa kuvaa. Tämän labyrintin osana he osallistuvat "feminaareihin" (féminaires), jossa naiseutta kuvaillaan sentimentaalisella ja naiivilla tavalla, kuten aiemmassa lainauksessa toin esiin. Mutta voittoisan sodan jälkeen naiset alkavat uutena lajina uuden kielen juhlavan etsinnän:

He sanovat, ota aikasi, tarkastele tätä uutta lajia, joka etsii uutta kieltä. Suuri tuuli pyyhkii maata. Aurinko nousee. Linnut eivät laula vielä. Taivaan lilat ja violetit värit kirkastuvat. He sanovat, mistä aiot aloittaa? He sanovat, vankilat on avattu ja käyvät öisistä turvapaikoista. He sanovat, että he ovat purkaneet sisäpuolen ja ulkopuolen käsitteet, että tehtaat on hajotettu, jok'ikinen, niiden seinä, että toimistot on siirretty ulkoilmaan penkereille, riisipelloille. He sanovat, on raskas erehdys, jos kuvitellaan, että minä, nainen, aion puhua väkivaltaisesti miehiä vastaan kun he ovat lakanneet olemasta vihollisiani. $(\mathrm{G}$, 189-190.) $)^{13}$

He haluavat korostaa eroaan aiemmasta hallitsevasta lajista, miehestä, joka on nyt 
menettänyt hegemoniansa, väkivaltaisen logiikkansa tuotteet ja symbolit, vankilat ja tehtaat. Wittigin kasvissyöjäamatsonit eivät korvaa patriarkaatin kahlitsevia rakenteita omalla terrorillaan tai väkivallalla, vaan naiseuden uudelleenmäärittelyyn ja uuden luomiseen tähtäävällä voimalla, joka kulkee teoksen kahden ensimmäisen osion johtomotiivina.

Myös Durasin Détruire, dit-elle -teoksen hirtehisessä lounaskeskustelussa hahmotellaan tulevaisuuden maailmaa:

- Entä te? hän kysyy, mitä te opetatte?

- Historiaa, sanoo Max Thor. Tulevaisuuden.

Hiljaisuus. Bernard Alione tuijottaa Max Thoria jähmettyneenä.

Bernard Alionen ääni on muuttunut tunnistamattomaksi.

- Onko se suurikin muutos? ääntää Bernard Alione.

- Ei ole enää mitään, sanoo Max Thor. Joten olen hiljaa. Oppilaani nukkuvat.

Hiljaisuus. Äkisti, tässä Élisabeth Alionen pehmeät itkunpurskahdukset.

- Onko vielä lapsia? hän kysyy.

- Muita ei olekaan, sanoo Max Thor.

Nainen hymyilee kyynelten läpi. Mies ottaa häntä kädestä.

- Ah, hän huokaisee, mikä onni. (DDE, 122-123. $)^{14}$

Puhuessaan kirjoittamisen politiikastaan Cahiers du cinéma -lehden haastattelussa Duras tapailee määritelmää epätoivon ja toivon väliselle halkeamalle. Hän kutsuu sitä ensin tyhjyydeksi, mutta tarkentaa sitten sen olevan nollapiste, neutri, jossa herkkyyden on mahdollista uudelleenjärjestyä. (Duras 1969, 54, ks. myös Just 2010, 360-361.) Jo Durasin varhemmissa teoksissakin paetaan merkityksen ahtaita rajoja ja annetaan tilaa negaation herkkyydelle, mutta Détruire, dit-elle -teoksen riisuttu kieli ja toisiaan kohti liukuvat, yhä viitteenomaisemmiksi muuttuvat henkilöhahmot puhdistavat pöytää kohti uutta, nollapisteeseen tähtäävää maailmanjärjestystä - tai epäjärjestystä.

\section{Lopuksi: 1968 - kertomuksen tilasta kirjoituksen tilaan}

Samalla tavoin kuin Kiinan kulttuurivallankumous oli Pariisin maolaisille kuin pienestä aukosta camera obscuran pimeään koppiin tunkeutuva nurinkurinen kuva, olivat toukokuiset toimintakomiteat Barthesin, Durasin ja Blanchot'n kaltaisille kirjallisille kokeilijoille pohjimmiltaan kirjallisen taistelukentän laajentuma. Näin muodon sisällä tempoileva voima ei ole vain suoraviivaista historiallisen kontekstin vaikutusta taiteeseen, vaan myös taiteilijan taipumus kanavoida aktivisminsa virtaamaan oman luovan projektinsa läpi. Toisaalta myös kirjailijoiden vallankumouksellisuudesta itsestään tuntuu tulleen poseeraava myytti. Patrick Combes $(2008,16)$ kuvaa, kuinka toukokuussa 1968 vallankumous ja kirjallisuus yhdistyivät "jos eivät ranskalaisessa todellisuudessa, niin ainakin hengessä”. Luonnehdinta piirtää tragikoomisen kuvan kirjailijasta, joka haluaisi osallistua, mutta jonka vallankumousromantiikka törmää kipeästi haljuun todellisuuteen (ks. myös sama, 269-270). ${ }^{15}$ 
Duras kuvaa Dionys Mascolon kirjoituskokoelmassa julkaistussa pienessä kirjoituksessa opiskelijain ja kirjailijain toimintakomitean hajanaista ja yskähtelevää toimintaa: aluksi paikalla oli monta kymmentä innostunutta, mutta toukokuun mittaan rivit harvenivat, eikä kollektiivinen tekstintuottaminen sujunut ongelmitta. Tämän Duras $(1993,327)$ kääntää voitoksi; juuri vaikeudessa piilee kollektiivisen tekemisen perimmäinen viehätys. Mascolo itse pitäytyy mantrassaan, jonka mukaan "teoria läpäisi kansanjoukot”. Hänen mukaansa on olennaista käsittää, että tämä teoretisoituminen ei ole vain kulttuurinen tai intellektuaalinen, vaan myös poliittinen ilmiö. Muuten sillä ei olisi merkitystä kuin kulttuuripiireille itselleen. (Mascolo 1993, 344, 355-357.)

Mutta vaikka poliittinen aktivismi näyttäytyisi lähinnä kertomusmuodon radikaalina kriisiyttämisenä, ei kirjailijoiden ja intellektuellien kumousponnistelua tarvitse silti leimata pelkäksi elämästä vieraantuneeksi diletantismiksi. Kuten Just luonnehtii, Durasin osallistuvuus kirjailijana oli anti-sartrelaista: tyhjiin uuvutettu lingvistinen tila avaa uusia suuntia tulevaisuuteen, koska se kyseenalaistaa koko käsityksemme persoonallisuudesta. Toisaalta hän jatkaa, että samalla Durasin agenda toki asettuu helpoksi maalitauluksi, sillä se ei suoranaisesti tarjoa mitään tyhjyyden tilalle. Duras tyhjentää vankilat, muttei muuta niitä turvapaikoiksi, kuten Wittig. Justin mukaan olennaista onkin huomata, että Duras provosoi paitsi lähestymään kielen, kertomuksen ja kulttuurin nollapistettä, myös laajentamaan käsitystämme estetiikan ja etiikan suhteesta. Nämä kaksi eivät ole erotettavissa toisistaan, vaan eettinen visio radikaalista intersubjektiivisuudesta löytää koekenttänsä häivytettyjen kertomuksen ja henkilöhahmojen estetiikasta. Toisin kuin Wayne C. Booth ja Martha Nussbaum, joille kirjallisuuden eettisyys toteutuu vain, jos se vakuuttaa lukijansa hyveellisestä agendastaan, Durasin versio etiikasta hylkää konkreettiset säännöstöt ja tähtää laajempaan, vähemmän moralistiseen käsitykseen. (Just 2010, 371, 373.) Uusi maailma hahmottuu vähemmän ilmeisellä tavalla, itse kertomusmuotoa sabotoimalla. Kieli ja kertominen liittyvät kiinteästi maailman hahmottamiseen, eikä ole vähäinen yritys pöyhiä niitä uuteen uskoon. Durasille tyhjyys on poliittinen ase tuhon polulla.

Jean-Louis Calvet'n kirjoittaman elämäkerran mukaan Roland Barthes pysytteli kaukana barrikadeista, vaikka intoutuikin pohtimaan "tapahtumien kielen" olemusta. Barthesia harmitti paitsi opiskelijamellakan pikkuporvarillinen luonne (tässä hän ei ollut yksin), myös se, että tapahtumien luonne suosi puhuttua sanaa ohi kirjoitetun. Hän tunsi jääneensä marginaaliin. (Calvet 1994, 164-166, 169.) Kirjoitetullakin sanalla kyllä oli sijansa erilaisina lentolehtisinä, iskulauseina ja seinäkirjoituksina, mutta nekin kumpusivat ennemmin paradoksaalisista nokkelista sanaleikeistä ("On kiellettyä kieltää", "Il est interdit d'interdire") ja puheenparresta.

Maurice Blanchot'n negatiiviseen kirjallisuuskäsitykseen tilanne sen sijaan istui kuin valettu. Blanchot'n haaveilema ei-kirja tuntui löytävän paikkansa ja mahdollisuutensa 
järjestelmän ulkopuolella. Toukokuun seinäkirjoitukset olivat hänelle jo innostava askel oikeaan suuntaan hätäisyydessään, luonnosmaisuudessaan ja epäjärjestyksessään. Toukokuussa ei ole kirjaa Toukokuusta, iloitsee Blanchot ja täsmentää:

Ei siksi, ettei olisi aikaa tai siksi että olisi pakko keskittyä "toimintaan", vaan paljon painavamman esteen vuoksi: se kirjoitetaan toisaalla, toimituskäytänteiltä ulottumattomassa maailmassa, se leviää poliisien nenän edessä ja tavallaan heidän avustamanaan: väkivaltana väkivaltaa vastaan. (Blanchot 1993, 157.) $)^{16}$

Toisin kuin Blanchot, Monique Wittig on myöhemmissä kirjoituksissaan vähemmän optimistinen kirjoituksen vapauden ja politiikan kytköksen suhteen. Hän suhtautuu epäillen sekä sitoutuneeseen kirjallisuuteen että "naiskirjoitukseen”, sillä hänen mukaansa kirjallisuuden kielen heterogeenisyydestä katoaa jotain olennaista, jos se sidotaan todellisuuteen. Hän haluaa pitää historian ja kirjallisuuden erillään. Edellinen kiinnittyy ihmisiin, jälkimmäinen muotoihin. (Wittig 1992b, 69-70.) Samoin politiikan ja poetiikan suhde huolestuttaa häntä: pelkistetäänkö kirja vain poliittisesti symboliksi tai manifestiksi, jolloin siitä tulee kirjallisesti hyödytön, se menettää monimerkitykselliset mahdollisuutensa yksiäänisyyden alttarilla? Jos näin käy, samalla hiipuu tekstin ainoa aito mahdollisuus poliittiseen toimintaan: punoa kirjallisuuden keinoin aikansa tekstuaaliseen kudokseen se, mitä teos kantaa mukanaan. (Wittig 1992a, 62-63.)

Mutta saavuttaakseen täyden monimerkityksellisyytensä vallankumouksellinen kirjallisuus tarvitsee kulttuurisen kontekstin, johon reagoida, jota vastaan kapinoida. Vaikka Barthesin hahmottelemalla, radikaalilla "nautinnon tekstillä" (texte de jouissance) on kyky horjuttaa historiallista ja kulttuurista perustaa, se on silti jossain määrin riippuvainen toisestaan, "mielihyvän tekstistä" (texte de plaisir). Barthes selventää konformistisen "mielihyvän tekstin" ja radikaalin "nautinnon tekstin" eroa osoittamalla, että juuri kompromissi, vaihtelu näiden kahden välillä luo kirjallisen tapahtuman: "Ei kulttuuri eikä sen tuho ole eroottista; näiden kahden välinen halkeama on se, josta tulee eroottinen.” (Barthes 1973, 25-26.) Vallankumouksellinen kertomusmuoto lymyää tekstinvälisissä marginaaleissa, tiloissa ja katkoksissa, kuten Les guérillères -teosta halkovan runon lopetuksessa:

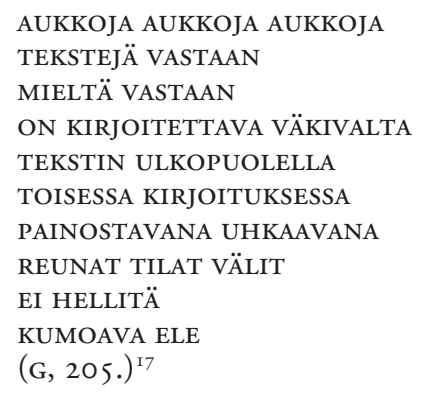


Niin Wittigin kuin Durasinkin teosten poeettiset ja poliittiset kohtaamiset, kerronnan kriisiyttäminen, muodostavat loppumattoman kumoavan eleen: tuhon ja uudelleen luomisen. Ele voi olla kirjoituksen kommunismia tai derridalaisittain différancen monimielinen, heilahduksin häilyvä merkityksen keinuliike (Derrida 1979, 206). Mutta venyttämällä kertomusta reunoista väleihin, puhkomalla sitä katkoksin kirjoitus muodostuu, kuten Genette luonnehti pari vuotta ennen mellakoita, ei enää vain välineeksi, vaan omaksi ajattelun tilakseen. Tämä tila mahdollistaa myös radikaalin liikehdinnän.

\section{Viitteet}

${ }^{1}$ Toisaalta taipumus aktivismiin oli vanhassa muistissa: moni vielä 1960- ja 1970-luvuilla vaikuttava intellektuelli, kuten Sartre ja Duras, oli jo kunnostautunut toisen maailmansodan vastarintaliikkeen aikana (Veivo 2007, 231).

2 "En Mai, il n'y a pas de livre sur Mai[.]" Kaikki suomennokset paitsi Cixous-lainaus omiani.

${ }^{3}$ Combesin alun perin vuonna 1984 ilmestynyt La littérature et le mouvement de Mai

68 (Éditions Seghers) oli ensimmäisiä kokonaiskartoituksia kirjallisuuden ja toukokuun liikehdinnän suhteesta. Combes on palannut aiheeseen ja päivittänyt tutkimuksensa l'Harmattan -kustantamon vuonna 2008 julkaisemaksi teokseksi Mai 68, les écrivains, la littérature. Viittaan tässä artikkelissa vain jälkimmäiseen, koska olennainen sisältö on sama.

${ }^{4}$ Durasin teosluettelossa esiintyy kylläkin epiteetti 'récit' ensin teoksen L'après-midi de Monsieur Andesmas (1962) ja myöhemmin vuoden 1982 teosten L'homme atlantique ja La maladie de la mort kohdalla. 'Récit' tarkoittaa kertomusta (vrt. Genetten Discours du récit), mutta on silti merkityksiltään väljempi kuin 'roman'.

${ }^{5}$ Myös Philippe Sollersin luotsaaman Tel Quel -ryhmän tai toisaalta Guy Debordin johtamien Kansainvälisten Situationistien (L'Internationale Situationniste) suhde toukokuun 1968 tapahtumiin ja maolaisuuteen olisi ristiriitaisuuksissaan kiintoisa tutkimuskohde, mutta yksittäisen artikkelin mittakaavassa katsoin selkeämmäksi jättää nämä tahot, kuten myös vuoden 1968 nuorisoidolin Jean-Paul Sartren, vähemmälle huomiolle.

${ }^{6}$ Durasin voimakkaan kirjailijahahmon ja autofiktiivisen tuotannon yhteenkietoutumista valottaa kiinnostavalla tavalla FM Netta Nakarin loppusuoralla oleva väitöstutkimus.

${ }^{7}$ Vaikka tässä artikkelissa en uppoudu metateoreettiseen keskusteluun piilevän tekijän problematiikasta, lienee paikallaan huomauttaa, että Tampereen yliopiston kertomuksentutkijoiden parissa on hienokseltaan kallistuttu tämän suomennoksen kannalle vakiintuneen 'sisäistekijän' sijaan. Näin siksi, että "implisiittinen tekijä" on usein vaivihkaisimmistakin vihjeistä esille loitsittava konstruktio, joka häilyy tekstin ja tulkinnan rajapinnassa eikä niinkään visusti sen sisällä.

8 'Uusi romaani' ei ollut mikään selvärajainen koulukunta ohjelmanjulistuksineen, mutta nimellä viitataan ranskalaisen kirjallisuuden yhteydessä 1950-luvun loppupuolella Minuitkustantamon kirjailijoiden, kuten Alain Robbe-Grillet'n, Nathalie Sarrauten, Michel Butorin, Robert Pinget'n ja Claude Simonin, romaaneihin, jotka pureutuvat objektien ja havainnon kuvaukseen konventionaalisemman juonikeskeisyyden asemesta.

${ }^{9}$ Suomentajat huomauttavat Cixous'n sanaleikin "la Prise de la Parole" viittaavan vuoden 1789 vallankumouksen aloittaneeseen Bastiljin valtaukseen (La Prise de la Bastille). Myös Roland Barthes (1968, 109) käyttää samaa sanaleikkiä esseessään "L'écriture de l'événement", jossa 
pohtii toukokuun mellakoiden leikkisän seinäkirjoituskielen olemusta ja mahdollisuuksia. 10 "Elles disent qu'elles ont trouvé des inscriptions sur des murs de plâtre où des vulves ont été dessinées comme les enfants dessinent les soleils avec de multiples rayons divergents. Elles disent qu'il a été écrit que les vulves sont des pièges des étaux des tenailles. [--] Elles disent que les vulves ont été comparées aux abricots aux grenades aux figues aux roses aux œillets aux pivoines aux marguerites. Elles disent qu’on peut réciter les comparaisons à la façon de litanies.”

11 "Ils sont dans l'ombre d'un arbre. Élisabeth revient lentement. Alissa ferme les yeux. Élisabeth s'allonge sur la chaise longue. Elle ferme les yeux à son tour. Sur son visage, le sourire du depart disparaît peu à peu pour laisser place à l'absence de toute expression."

12 ”- Vous vous intéressez beaucoup à elle, décidément, dit Bernard Alione.

- Oui.

- On peut savoir pourquoi? - la voix a repris de la force.

- Pour des raisons littéraires, dit Stein. Il rit.

Stein rit. Alissa le regarde rire dans l'éblouissement.

- Ma femme est un personnage de roman? dit Bernard Alione.

Il ricane. Sa voix est toujours aussi blanche malgré l'effort.

$[--]$

- Je ne vois pas ce que vous pourriez raconter sur elle... C'est vrai que maintenant on ne raconte plus rien dans les romans... C'est pour ça que j'en lis si peu... que...

Il les regarde. Ils sont devenus sérieux. Ils ne l'écoutent pas. Élisabeth traverse la salle à manger. Elle s'assied. Ses yeux sont restés grand ouverts sur le sommeil.

Silence.

- Vous avez vomi? demande Alissa.

Élisabeth a beaucoup de mal à former ses mots.

- Oui.

- Comment était-ce?

Élisabeth réfléchit. Elle sourit.

- Agréable, dit-elle.

- Bien, dit Stein, bien.”

13 "Elles disent, prends ton temps, considère cette nouvelle espèce qui cherche un nouveau langage. Un grand vent balaie la terre. Le soleil va se lever. Les oiseaux ne chantent pas encore. Les couleurs lilas et violet du ciel s'éclaircissent. Elles disent, par quoi vas-tu commencer? Elles disent, les prisons sont ouvertes et servent d'asiles de nuit. Elles disent qu'elles ont rompu avec la notion de dedans et de dehors, que les usines ont abattu, chacune, un de leurs murs, que les bureaux ont été installés en plein air sur les digues, dans les rizières. Elles disent, on se trompe fort si l'on s'imagine que j'irai, moi, femme, parler avec violence contre les hommes quand ils ont cessé d'être mes ennemis."

14 "- Et vous? demande-t-il, qu'est-ce que vous enseignez?

- L'histoire, dit Max Thor. De l'avenir.

Silence. Bernard Alione fixe Max Thor, immobile.

La voix de Bernard Alione est devenue méconnaissable.

- C'est un grand changement? prononce Bernard Alione.

- Il n'y a plus rien, dit Max Thor. Alors je me tais. Mes élèves dorment.

Silence. Tout à coup, voici les doux sanglots d'Élisabeth Alione. 
- Il y a encore des enfants? demande-t-elle.

- Il n'y a plus que ça, dit Max Thor.

Elle sourit à travers ses larmes. Il lui prend la main.

- Ah, gémit-elle, quel bonheur."

${ }^{15}$ Kevään 1968 tutkimukset ja dokumentit antavat tylyn kuvan teoreetikkojen ja opiskelijaaktivistien suhteen luonteesta. Sekä Richard Wolin (2010, 193), Patrick Combes (2008, 97) että Gilles Bousquet (1993, 205-206) siteeraavat mellakoiden johtotähden Daniel Cohn-Bendit'n lausuntoa, jonka mukaan kukaan ydinjoukosta ei ollut lukenut liikehdinnän innoittajana pidettyä Herbert Marcusea. "Jotkut lukevat Marxia, tietenkin, ehkä Bakuninia ja aikalaisajattelijoista Althusseria, Maoa, Guevaraa, [Henri] Lefebvreä. Käytännössä kaikki Maaliskuun 22. päivän liikkeen militantit ovat lukeneet Sartrea." Sartren merkitystä korostavassa luvussaan Wolin katkaisee sitaatin strategisesti tähän, mutta Combes ja Bousquet paljastavat Cohn-Bendit’n arviosta loputkin: "Mutta ketään kirjailijaa ei voi pitää liikkeen innoittajana."

16 "En Mai, il n'y a pas de livre sur Mai: non par manque de temps ou par nécessité 'd'agir', mais par un empêchement plus décisif; cela s'écrit ailleurs, dans un monde privé d'édition, cela se diffuse face à la police et d'une certaine manière avec son aide, violence contre violence."

17 "LACUNES LACUNES LACUNES

CONTRE TEXTES

CONTRE SENS

CE QUI EST A ECRIRE VIOLENCE

HORS TEXTE

DANS UNE AUTRE ECRITURE

PRESSANT MENAÇANT

MARGES ESPACES INTERVALLES

SANS RELACHE

GESTE RENVERSEMENT.”

\section{Lähteet}

Barthes, ROland i968: L'écriture de l'événement. Communications 12, 108-112.

Barthes, ROland I 973: Le plaisir du texte. Paris: Éditions du Seuil.

Barthes, ROland 2000/r970: S/Z. Paris: Éditions du Seuil.

BLANCHOt, MAURICE 2006/1969: Entretien infini. Paris: Gallimard.

Blanchot, MaUrice 2008: Écrits politiques. 1953-1993. Éd. Éric Hoppenot. Paris: Gallimard.

BOlgár, MIRJa I969: Pariisin päiviä. Kirjoja ja kirjailijoita. Helsinki: WSOY. BousQuet, GILLeS I993: Apogée et déclin de la modernité. Regards sur les années 60. Paris: Éditions l'Harmattan.

BRILLANT, BERNARD 2003: Les clercs de 68. Paris: Presses Universitaires de France. CAlvet, JeAn-Louis i 994: Roland Barthes. A Biography (Roland Barthes, 1990). Käänt. Sarah Wykes. Cambridge: Polity Press.

CIXOUS, HéLÈne 2013: Medusan nauru ja muita ironisia kirjoituksia (Le Rire de la Méduse 
et autres ironies, 2010). Suom. Heta Rundgren \& Aura Sevón. Helsinki: Tutkijaliitto. COMBES, PATRICK 2008: Mai 68, les écrivains, la littérature. Paris: Éditions l'Harmattan. DARBY, DAVID 200I: Form and Context. An essay in the History of Narratology. Poetics Today 22 (4), 829-852.

DERRIDA, JACQUeS I997/I967: De la grammatologie. Paris: Les Éditions de Minuit. DERRIDA, JACQUES 2010/1967: L'écriture et la différence. Paris: Éditions du Seuil.

DOSSE, FRANÇOIS I 997: History of Structuralism. Volume 2: The Sign Sets. 1967-Present (Histoire du structuralisme, II. Le chant du cygne, de 1967 à nos jours, 1992). Trans. Deborah Glassman. Minneapolis \& London: University of Minneasota Press. DURAS, MARguerite I 969: La destruction la parole. Cahiers du cinéma 217, 45-57. DURAS, MARGUERITE I993/I 968: Naissance d'un comité. Dionys Mascolo, À la recherche d'un communisme de pensée. Entêtements. Paris: Fourbis, 324-330.

Duras, Marguerite 2007/1969: Détruire, dit-elle (= DDE). Les éditions de Minuit. Paris.

FLUDERnik, MONIKA 2005: Histories of Narrative Theory (II): From Structuralism to the Present. A Companion to Narrative Theory. Ed. James Phelan \& Peter J. Rabinowitz. Malden et al.: Blackwell.

GENETTE, GÉRARD I 969: Figures II. Paris: Éditions du Seuil.

GRIFFIN CROWDER, DIANE 2005: Universalizing Materialist Lesbianism. On Monique Wittig. Theoretical, Political, and Literary Essays. Ed. Namascar Shaktini. Urbana \& Chicago: University of Illinois Press.

GROSZ, ELISAZABETH 2013: Sukupuoliero ja essentialismin ongelma (Sexual Difference and the Problem of Essentialism, 1989). Suom. Elina Halttunen-Riikonen. niin \& näin 3 (13), 61-71.

JUST, DANiel 20 Io: Aesthetics of Blankness: Political Imagination in Marguerite Duras's Hybrid Narratives. The Romanic Review 101 (3), 359-376.

MASCOLO, Dionys I993: À la recherche d'un communisme de pensée. Entêtements. Paris: Fourbis.

MCHALE, BRIAN 2005: Ghosts and Monsters: On the (Im)Possibility of Narrating the History of Narrative Theory. A Companion to Narrative Theory. Ed. James Phelan \& Peter Rabinowitz. Malden et al.: Blackwell Publishing.

MERETOJA, HANNA 2007: Ranskalainen uusi romaani avantgarde-kirjallisuuden suuntauksena. Kirjallisuuden avantgarde ja kokeellisuus. Toim. Sakari Katajamäki \& Harri Veivo. Helsinki: Gaudeamus.

meretoja, hanna 20Io: The French Narrative Turn. From the Problematization of Narrative Subjectivity in Alain Robbe-Grillet's Dans le labyrinthe to its Hermeneutic Rehabilitation in Michel Tournier's Le Roi des Aulnes. Turku: Turun yliopiston julkaisuja, Annales Universitatis Turkuensis B 329. 
NANCY, JEAn-LuC 20io: Tunkeilija (L'intrus, 2000). Suom. Elia Lennes ja Kaisa Sivenius. Filosofin sydän. Toim. Sami Santanen. Helsinki: Gaudeamus.

RICHARDSON, BRIAN 2006: Unnatural Voices. Extreme Narration in Modern and Contemporary Fiction. Columbus: Ohio State University Press.

ROBbe-GRILlet, ALAIN 200 I: Le voyageur. Textes, causeries, entretiens (1947-2001). Paris: Christian Bourgois Éditeur.

Shaktini, NAMASCar 2005: On Monique Wittig. Theoretical, Political, and Literary Essays. Urbana \& Chicago: University of Illinois Press.

SHEN, DAN 2005: Why Contextual and Formal Narratologies Need Each Other. Journal of Narrative Theory 2 (35), 141-171.

veIvo, HARri 2007: Oulipo ja Tel Quel. Muoto, politiikka ja potentiaalisuus. Kirjallisunden avantgarde ja kokeellisuus. Toim. Sakari Katajamäki \& Harri Veivo. Helsinki: Gaudeamus.

VIART, DOMINIQUe 2008: Les héritages de Mai 68. Écrire, Mai 68. Éds. Emmanuel Adely et al. Paris: Argol editions.

witTig, Monique I992A: The Point of View: Universal or Particular? (Avant-note, 1980). The Straight Mind and Other Essays. New York et al.: Harvester Wheatsheaf.

witTig, MONIQUe I992в: The Trojan Horse (1984). The Straight Mind and Other Essays. New York et al.: Harvester Wheatsheaf.

wittig, Monique I992C: The Mark of Gender (1985). The Straight Mind and Other Essays. New York: Harvester Wheatsheaf.

wittig, moniQue 2005/1969: Les guérillères $(=\mathrm{G})$. Les éditions de Minuit. Paris.

WitTig, MONiQue 2005/I994: Some Remarks on Les guérillères. Trans. Namascar Shaktini. On Monique Wittig. Theoretical, Political, and Literary Essays. Ed. Namascar Shaktini. Urbana \& Chicago: University of Illinois Press.

WOLIN, RICHARD 20IO: The Wind from the East. French Intellectuals, the Cultural Revolution, and the Legacy of the 1960s. Princeton \& Oxford: Princeton University Press. 